\title{
How to Attract Interest in Health Materials: Lessons from Psychological Studies
}

\author{
Tsuyoshi Okuhara*, Hirono Ishikawa, Masahumi Okada, Mio Kato, Takahiro Kiuchi \\ Department of Health Communication, School of Public Health, The University of Tokyo, Tokyo, Japan \\ Email: *okuhara-ctr@umin.ac.jp
}

How to cite this paper: Okuhara, T., Ishikawa, H., Okada, M., Kato, M. and Kiuchi, T. (2018) How to Attract Interest in Health Materials: Lessons from Psychological Studies. Health, 10, 422-433.

https://doi.org/10.4236/health.2018.104034

Received: March 21, 2018

Accepted: April 22, 2018

Published: April 25, 2018

Copyright $\odot 2018$ by authors and Scientific Research Publishing Inc. This work is licensed under the Creative Commons Attribution International License (CC BY 4.0).

http://creativecommons.org/licenses/by/4.0/

(c) (i) Open Access

\begin{abstract}
Objective: Health materials need to target individuals who resist or are not interested in health behaviors. Attracting the interest of this audience is a crucial aspect of materials' design. The present study aimed to review the findings of psychological studies on causes of interest and to discuss the applicability of these studies to the design of health materials. Methods: We used the backward and forward snowball method for our literature review. We identified 10 relevant publications as initial sources for snowballing through a systematic search of EBSCOhost (searching PsycINFO, PsycARTICLES, ERIC, CINAHL and MEDLINE). Through backward and forward snowballing from these sources, 76 relevant publications were identified. Results: We identified properties and variables relevant to attracting interest and grouped them into four tactics: surprise; question; visualization; emotional appeal. Conclusion: Lessons from psychology gained in the present study may guide future studies and practices for attracting interest in health materials. The four tactics can be used to make health materials more interesting, as an example showed in the present study.
\end{abstract}

\section{Keywords}

Health Material, Health Education, Attention, Interest, Comprehension, Memory

\section{Introduction}

Health materials help individuals to understand and engage in the management of their health conditions. Written or audiovisual health materials are designed and disseminated to individuals by health professionals. These health materials convey important health education messages such as recommendations for cancer screenings, vaccinations, healthy diet, and physical activity. The primary challenge in designing health materials is to preferentially target individuals who 
resist or are not interested in health behaviors [1]. McGuire's communication and persuasion matrix indicate that attracting attention and interest of this audience is the first step toward promotion of health behaviors [2] [3] [4]. Furthermore, studies indicate that when audiences are interested in the given information, their learning, comprehension, and recall are enhanced [5] [6]. Therefore, attracting the interest of the audience is crucial in the design of health materials.

Numerous studies in psychology have sought to determine which stimulus properties attract interest. Sharing of these findings with researchers and practitioners in health education will contribute to better design of health materials. The present study aimed to review the psychological literature on causes of interest, and to discuss the applicability of those findings to the study and practice of designing of health materials.

\section{Methods}

We adopted the backward and forward snowball method proposed by Greenhalgh et al. [7] [8] [9] because search terms such as "interest" generated a large volume of results. To identify initial sources for the snowballing, we conducted a systematic search of EBSCOhost (searching PsycINFO, PsycARTICLES, ERIC, CINAHL and MEDLINE) to identify relevant review articles and books published in English between January 1990 and 2017. The search terms were: attention OR interest OR curiosity OR liking. We excluded irrelevant results by selecting subjects. The search yielded 535 publications. After title and abstract analysis, we excluded 499 publications because of irrelevance to the aim of the present study. We analyzed the full text of the remaining 36 publications; in this process, 26 publications were excluded, and 10 publications were included as initial sources. From these sources, we gathered relevant publications by backward reference snowballing and forward citation snowballing using the Web of Science. As a result, we identified 76 relevant publications and subsequently reviewed them (Figure 1).

\section{Results}

As Table 1 shows, we identified 15 message variables. According to McGuire's communication and persuasion matrix indicate [2] [3] [4], the message variables are the independent variables, and the output variables are the dependent variables that respond to the message variables. As McGuire [2] has mentioned, some of the message variables influenced multiple output variables (e.g., questions attract interest and improve memory). We integrated similar message variables and grouped them into four categories: surprise; question; visualization; emotional appeal.

\subsection{Surprise}

Berlyn [10] [11] [12] was one of the first researchers to investigate environment-based causes of interest. According to him, interest is a function of collative 


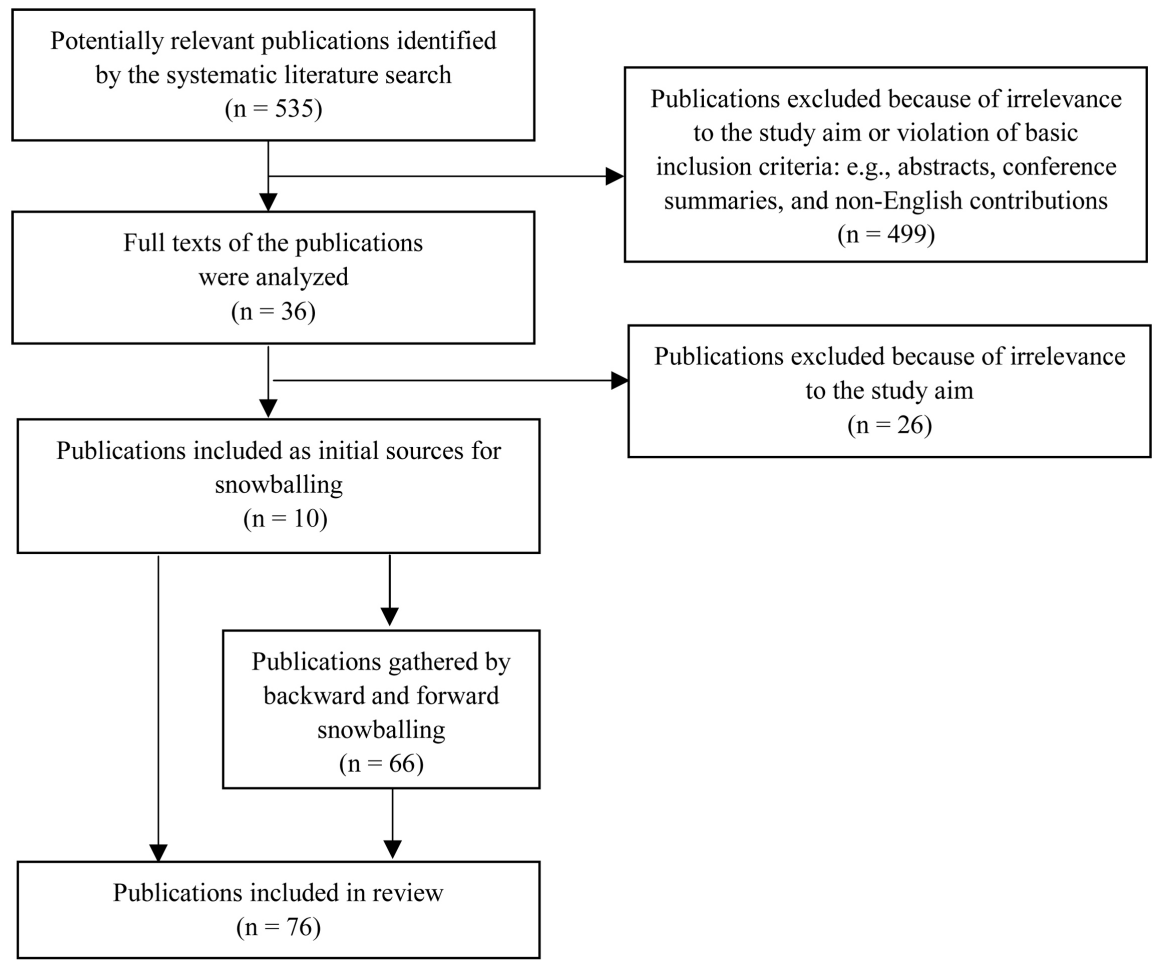

Figure 1. Analysis of the identified contributions.

variables, which he defined as structural properties of stimulus patterns, such as familiar-novel and expected-surprising [12]. The underlying characteristic of these properties is that they create conflict [10] [11] [12]. Similarly, other scholars have proposed that information conflict [13], incongruity [14] [15] [16], and structural anomaly [17] attract interest.

Hidi [18] reviewed these evidences and proposed message variables such as unexpectedness [19], surprise [20] [21] and novelty [22] attract interest. Lowenstein [23] argued similarly that interest is aroused when the given information violates one's expectations or is incongruous with one's existing ideas, because these situations interfere with the natural tendency to try to make sense of the world. This construct encompasses properties such as novelty and surprise [23]. Wade et al. [24] and Silvia [25] conducted empirical studies to test these message variables, and concluded that they attract interest.

The public advertisement presented by a partnership between the health and community organizations in Australia, "Rethink Sugary Drink", is an example of using a tactic of surprise, within which fat comes out from a can when a man drinks a sugary drink [26]. Health professionals are advised to convey unexpected and surprising messages in health materials to attract interest of audiences. For an example, see Figure 2 (to be discussed later).

\subsection{Question}

As is generally accepted, mystery is a powerful inducer of interest that does not need personal relevance, but brings its own relevance in the form of a need for 
Table 1. Message variables, categories, output variables and key references.

\begin{tabular}{|c|c|c|c|}
\hline Categories & Message variables & Output variables & Key references \\
\hline \multirow{6}{*}{ Surprise } & Conflict & Interest/liking & $\begin{array}{c}\text { Berlyn, 1960, 1974; } \\
\text { Nunnally \& Lemond, } 1973\end{array}$ \\
\hline & Incongruity & Interest/liking & $\begin{array}{l}\text { Hunt, 1963, 1965; } \\
\text { Mandler, } 1982\end{array}$ \\
\hline & Structural anomaly & Interest/liking & Lepper, 1988 \\
\hline & Surprise & Interest/liking & $\begin{array}{l}\text { Hidi \& Baird, 1986; } \\
\text { Iran-Nejad, } 1987\end{array}$ \\
\hline & Unexpectedness & Interest/liking & $\begin{array}{c}\text { Schank, 1979; } \\
\text { Wade et al., } 1999\end{array}$ \\
\hline & Novelty & Interest/liking & $\begin{array}{l}\text { Anderson et al., 1987; Wade } \\
\text { et al., 1999; Silvia, } 2005\end{array}$ \\
\hline \multirow{4}{*}{ Question } & Mystery & Interest/liking & $\begin{array}{c}\text { Cialdini, 2005; } \\
\text { Kruglanski \& Webster, } 1996\end{array}$ \\
\hline & Information gap & Interest/liking & Loewenstein, 1994 \\
\hline & & Interest/liking & $\begin{array}{c}\text { Berlyn, 1960; } \\
\text { Loewenstein, 1994 }\end{array}$ \\
\hline & Question & Recall & $\begin{array}{c}\text { Slamecka \& Graf, 1978; } \\
\text { Pressley et al., 1987; Mulligan } \\
\text { \& Lozito, } 2004\end{array}$ \\
\hline \multirow{10}{*}{ Visualization } & & Interest/liking & Wade et al., 1999; \\
\hline & Imagery & Comprehension & Clark and Paivio, 1991 \\
\hline & & Recall & Clark and Paivio, 1991 \\
\hline & Vivid detail & Interest/liking & Schraw et al., 1995 \\
\hline & Concreteness & Recall & $\begin{array}{l}\text { Wharton, 1980; Sadoski et al., } \\
\text { 1993; Sadoski et al., } 2000\end{array}$ \\
\hline & & Attention & Delp \& Jones, 1996; \\
\hline & & Comprehension & $\begin{array}{l}\text { Michielutte et al., 1992; } \\
\text { Austin et al., 1995; } \\
\text { Morrow et al., 1998; } \\
\text { Mansoor \& Dowse, } 2003\end{array}$ \\
\hline & Pictures & Recall & $\begin{array}{c}\text { Patel et al., 1990; Delp \& } \\
\text { Jones, 1996; Sojourner \& } \\
\text { Wogalter; } 1998\end{array}$ \\
\hline & & Decision making & $\begin{array}{l}\text { Roter et al., 1987; } \\
\text { Delp \& Jones, 1996; } \\
\text { Whatley et al., } 2002\end{array}$ \\
\hline & Metaphor/analogy & Comprehension & $\begin{array}{l}\text { Mio, 1996; Gentner \& } \\
\quad \text { Markman, } 1997\end{array}$ \\
\hline \multirow[b]{3}{*}{$\begin{array}{l}\text { Emotional } \\
\text { appeal }\end{array}$} & & Attention & Yiend, 2010;Carretié, 2014. \\
\hline & & Interest/liking & Schank,1979; Kintsch, 1980 \\
\hline & Emotional arousing & Recall & $\begin{array}{c}\text { Sadoski \& Quast, 1990; } \\
\text { Schmolck et al., 2000; } \\
\text { Hamann, 2001; } \\
\text { Buchanan \& Adolphs, } 2002\end{array}$ \\
\hline
\end{tabular}




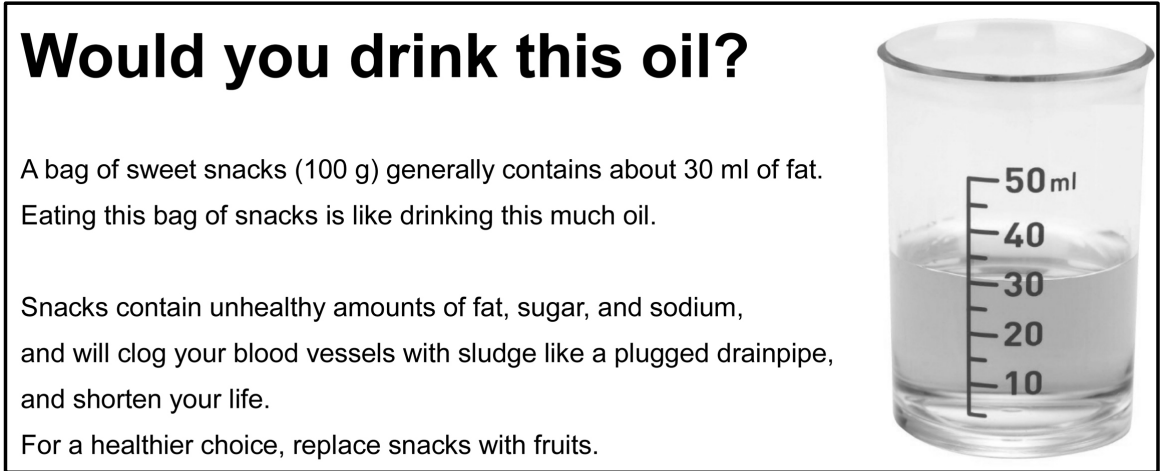

Figure 2. Application example, using surprise, question, visualization and emotional appeal.

closure [27] [28]. The power of mystery as an inducer of interest is informed by Loewenstein and Litman's conceptions of interest. According to Loewenstein [23], interest is a form of cognitively induced deprivation. This deprivation arises when individuals perceive a gap in their knowledge or a gap between what they know and what they want to know [23]. This state motivates a desire to know. According to Litman, the desire stimulates acquisition of new information [29], which brings an eventual experience of pleasure from closing the information gap [30]. Accordingly, the posing of questions confronts the recipient directly with an information gap, and can be the most straightforward inducer of interest [10] [23].

Additionally, recipients remember information better when they must generate possible answers to a question; such findings have been labeled as a "generation effect" [31]. For example, pairs of antonyms in which some information is concealed and must be generated by the reader (e.g., fast_-s__) are better recalled than are pairs in which all information is presented (e.g., fast-slow) [32].

Health professionals are advised to present riddles or questions in health materials to allow audiences to process the information actively. For example, a headline with a question such as " $99 \%$ vs $15 \%$-do you know what the numbers mean?" will attract interest more than a simple headline such as "Obtain breast cancer screening regularly".

\subsection{Visualization}

Studies indicate that when written health materials are presented with pictures, they attract more attention [33] as well as facilitate comprehension [34] [35] [36] [37] and aid recall [33] [38] [39] and decision-making [40] [41] [42] (see Houts et al. [43] for a review). A simple graphic of the USDA Myplate Nutrition Guideline [44] is a good example of visualization. The graphical guideline improved respondents' recall and food choices compared with a previous complex graphic [45].

This effect can be explained by dual coding theory [46], which assumes that both verbal and nonverbal (e.g., visualized) mental encoding of information 
yields additive increases in comprehension and retention. Dual coding is prompted by concrete language even without pictorial cues [47] [48]. Studies indicate that concrete words stimulate greater generation of imagery [49] [50] and that concrete descriptions with vivid details are more interesting [24] [51], more comprehensible [52] [53] [54], and more memorable [55] [56] [57] than is abstract text.

Sadoski [54] suggests that important but abstract messages should be fleshed out with connected concrete examples. Metaphors can be used to express an abstract concept in a concrete form. For example, to explain atherosclerosis simply, health professionals can describe it as "like a kitchen drain pipe becoming gradually plugged with cooking grease and sludge". Metaphors also make an argument easier to comprehend [58] [59] and are consequently more persuasive than literal messages [60].

\subsection{Emotional Appeal}

Schank [19] suggested that life themes such as danger and death are "absolute interests", i.e., they elicit individuals' interest almost universally. Kintsch [61] referred to them as "emotional interests." Studies indicate that both negative and positive emotional arousal information elicits selective attentional priority over non-emotional information [62] [63].

Studies also indicate that strength of emotional arousal is correlated with recall rates [55] [64] [65] [66]. This finding has been documented with a variety of stimuli, including words, sentences and pictures [67] [68] [69]. Neuroimaging studies have demonstrated that amygdala activation plays a fundamental role in consolidating memory for emotional information [70] [71] when an individual processes threat-related as well as reward-related information [72] [73] [74].

The public advertisement "Make Health Last", created by the Canadian Heart and Stroke Foundation [75], is an example of emotional appeal by contrast between costs of not performing health behaviors and benefits of performing them.

\section{Discussion}

The present study showed properties relevant to attracting interest as well as enhancing comprehension and memory. The properties can be instantiated with four tactics: surprise, question, visualization, and emotional appeal. Although we cannot deny the possibility that relevant publications were missed in the present review, the "snowball" method we used is powerful for identifying high-quality sources in obscure locations [7]. Although the present study is an exploratory review of literatures to examine properties relevant to attracting interest in health materials, it has implications, as follows. Studies and practices of designing health materials so far have focused on lowering the barriers to health information for those with low literacy skills [76]-[83]. To our knowledge, the properties and variables revealed in the present study have not received sufficient attention in studies of designing health materials to attract the interest of 
audiences. Future studies may assess the extent to which the variables that emerged in the present study affect audiences' interest as well as comprehension and memory. It may also be useful to examine the effect of combining these variables in the design of health materials (e.g., Figure 2) on audiences' intention to perform health behaviors.

Figure 2 shows an example of using the four tactics introduced in the present study. When health materials try to inform about health risks of indulging in too many confectionary snacks, a mediocre message such as, "Replace snacks with fruits" may not successfully attract the interest of target audiences. The headline in Figure 2, "Would you drink this oil?" uses a question. Sentences like the following offer a surprise: “A bag of sweet snacks (100 g) generally contains about $30 \mathrm{ml}$ of fat". A picture of a measuring cup with oil visualizes this surprising message. A metaphor of a plugged drainpipe visualizes the abstract idea of atherosclerosis. A sentence like the following is intended to appeal to the audience's

emotions: "Snacks contain unhealthy amounts of fat, sugar, and sodium, and will clog your blood vessels with sludge like a plugged drainpipe, and shorten your life". Thus, the tactics showed in the present study can make health materials more interesting.

Health education and promotion begin with attracting the interest of audiences [2] [3] [4]. If health materials are successful in this, they will be able to promote health more effectively. Studies in psychology may guide the future studies and practices in health education to attract interest in health materials.

\section{Funding}

This work was supported by a Japan Society for the Promotion of Science KAKENHI (grant number 167100000384).

\section{References}

[1] Atkin, C.K. and Salmon C. (2013) Persuasive Strategies in Health Campaigns. In: Dillard, J.P. and Shen, L., Eds., The SAGE Handbook of Persuasion: Developments in Theory and Practice, 2nd Edition, SAGE Publications, Thousand Oaks, 278-295.

[2] McGuire, W.J. (1985) Attitudes and Attitude Change. In: Lindzey, G. and Aronson, E., Eds., The Handbook of Social Psychology, Vol. 2. Special Fields and Applications, 3rd Edition, Random House, New York, 233-346.

[3] McGuire, W.J. (2001) Input and Output Variables Currently Promising for Constructing Persuasive Communications. In: Rice, R.E. and Atkin, C.K., Eds., Public Communication Campaigns, 3rd Edition. SAGE Publications, Thousand Oaks, 22-48. https://doi.org/10.4135/9781452233260.n2

[4] McGuire, W.J. (2013) McGuire's Classic Input-Output Framework for Constructing Persuasive Messages. In: Rice, R.E. and Atkin, C.K., Eds., Public Communication Campaigns, 4th Edition, SAGE Publications, Thousand Oaks, 133-146. https://doi.org/10.4135/9781544308449.n9

[5] Hidi, S. (2001) Interest, Reading, and Learning: Theoretical and Practical Considerations. Educational Psychology Review, 13, 191-209.

https://doi.org/10.1023/A:1016667621114 
[6] Schraw, G. and Lehman, S. (2001) Situational Interest: A Review of the Literature and Directions for Future Research. Educational Psychology Review, 13, 23-52. https://doi.org/10.1023/A:1009004801455

[7] Greenhalgh, T. and Peacock, R. (2005) Effectiveness and Efficiency of Search Methods in Systematic Reviews of Complex Evidence: Audit of Primary Sources. British Medical Journal, 331, 1064-1065. https://doi.org/10.1136/bmj.38636.593461.68

[8] Greenhalgh, T., Robert, G., MacFarlane, F., Bate, P. and Kyriakidou, O. (2004) Diffusion of Innovations in Service Organizations: Systematic Review and Recommendations. Milbank Quarterly, 82, 581-629.

https://doi.org/10.1111/j.0887-378X.2004.00325.x

[9] Greenhalgh, T., Robert, G., Macfarlane, F., Bate, P., Kyriakidou, O. and Peacock, R. (2005) Storylines of Research in Diffusion of Innovation: A Meta-Narrative Approach to Systematic Review. Social Science Medicine, 61, 417-430. https://doi.org/10.1016/j.socscimed.2004.12.001

[10] Berlyne, D.E. (1960) Conflict, Arousal, and Curiosity. McGraw-Hill, New York. https://doi.org/10.1037/11164-000

[11] Berlyne, D.E. (1971) Aesthetics and Psychobiology. Appleton-Century-Crofts, New York.

[12] Berlyne, D.E. (1974) Studies in the New Experimental Aesthetics: Steps toward an Objective Psychology of Aesthetic Appreciation. Hemisphere, Washington, 5.

[13] Nunnally, J.C. and Lemond, L.C. (1973) Exploratory Behavior and Human Development. Advances in Child Development and Behavior, 8, 59-109. https://doi.org/10.1016/S0065-2407(08)60493-0

[14] Hunt, J.M. (1963) Motivation Inherent in Information Processing and Action. In: Harvey, O.J., Ed., Motivation and Social Interaction, Ronald, New York, 35-94.

[15] Hunt, J.M. (1965) Intrinsic Motivation and Its Role in Psychological Development. In: Levine, D., Ed., Nebraska Symposium on Motivation, Vol. 13, University of Nebraska Press, Lincoln, 189-282.

[16] Mandler, G. (1982) The Structure of Value: Accounting for taste. In: Clark, M.S. and Fiske, S.T., Eds., Affect and Cognition, Lawrence Erlbaum Associates, Hillsdale, 3-36.

[17] Lepper, M.R. (1988) Motivational Considerations in the Study of Instruction. Cognition and Instruction, 5, 289-309. https://doi.org/10.1207/s1532690xci0504_3

[18] Hidi, S. (1990) Interest and Its Contribution as a Mental Resource for Learning. Review of Educational Research, 60, 549-571. https://doi.org/10.3102/00346543060004549

[19] Schank, R.C. (1979) Interestingness: Controlling inferences. Artificial Intelligence, 12, 273-297. https://doi.org/10.1016/0004-3702(79)90009-2

[20] Hidi, S. and Baird, W. (1986) Interestingness-A Neglected Variable in Discourse Processing. Cognitive Science, 10, 179-194.

[21] Iran-Nejad, A. (1987) Cognitive and Affective Causes of Interest and Liking. Journal of Educational Psychology, 7, 120-130. https://doi.org/10.1037/0022-0663.79.2.120

[22] Anderson, R.C., Shirey, L.L., Wilson, P.T. and Fielding, L.G. (1987) Interestingness of Children's Reading Material. In: Snow, R.E. and Farr, M.J., Eds., Aptitude, Learning and Instruction: Vol. III, Cognitive and Affective Process Analyses, Erlbaum, Hillsdale, 287-299.

[23] Loewenstein, G. (1994) The Psychology of Curiosity: A Review and Reinterpretation. Psychological Bulletin, 116, 75-98. https://doi.org/10.1037/0033-2909.116.1.75 
[24] Wade, S.E., Buxton, W.M. and Kelly, M. (1999) Using Think-Alouds to Examine Reader-Text Interest. Reading Research Quarterly, 34, 194-216. https://doi.org/10.1598/RRQ.34.2.4

[25] Silvia, P.J. (2005) What Is Interesting? Exploring the Appraisal Structure of Interest. Emotion, 5, 89-102. https://doi.org/10.1037/1528-3542.5.1.89

[26] Rethink Sugary Drink (2018) A Partnership between the Health and Community Organizations. http://www.rethinksugarydrink.org.au/about

[27] Cialdini, R. (2005) What's the Best Secret Device for Engaging Student Interest? The Answer Is in the Title. Journal of Social and Clinical Psychology, 24, 22-29. https://doi.org/10.1521/jscp.24.1.22.59166

[28] Kruglanski, A. and Webster, D. (1996) Motivated Closing of the Mind: "Seizing" and "Freezing". Psychological Review, 103, 263-283. https://doi.org/10.1037/0033-295X.103.2.263

[29] Litman, J.A. (2005) Curiosity and the Pleasures of Learning: Wanting and Liking New Information. Cognition and Emotion, 19, 793-814. https://doi.org/10.1080/02699930541000101

[30] Litman, J.A. and Jimerson, T.L. (2004) The Measurement of Curiosity as a Feeling of Deprivation. Journal of Personality Assessment, 82, 147-157. https://doi.org/10.1207/s15327752jpa8202_3

[31] Mulligan, N.W. and Lozito, J.P. (2004) Self-Generation and Memory. Psychology of Learning and Motivation, 45, 175-214. https://doi.org/10.1016/S0079-7421(03)45005-6

[32] Slamecka, N.J. and Graf, P. (1978) The Generation Effect: Delineation of a Phenomenon. Journal of Experimental Psychology Human Learning and Memory, 4, 592-604. https://doi.org/10.1037/0278-7393.4.6.592

[33] Delp, C. and Jones, J. (1996) Communicating Information to Patients: The Use of Cartoon Illustrations to Improve Comprehension of Instructions. Academic Emergency Medicine, 3, 264-270. https://doi.org/10.1111/j.1553-2712.1996.tb03431.x

[34] Michielutte, R., Bahnson, J., Digman, M.B. and Schroeder, E. (1992) The Use of Illustrations and Narrative Text Style to Improve Readability of a Health Education Brochure. Journal of Cancer Education, 7, 251-260.

[35] Austin, P.E., Matlack, R., Dunn, K.A., Kosler, C. and Brown, C.K. (1995) Discharge Instructions: Do Illustrations Help Our Patients Understand Them? Annals of Emergency Medicine, 25, 317-320. https://doi.org/10.1016/S0196-0644(95)70286-5

[36] Morrow, D.G., Hier, C.M., Menard, W.E. and Leirer, V.O. (1998) Icons Improve Older and Younger Adults' Comprehension of Medication Information. Journal of Gerontology, 53B, 240-254. https://doi.org/10.1093/geronb/53B.4.P240

[37] Mansoor, L.E. and Dowse, R. (2003) Effect of Pictograms on Readability of Patient Information Materials. Annals of Pharmacotherapy, 37, 1003-1009. https://doi.org/10.1345/aph.1C449

[38] Patel, V.L., Eismon, T.O. and Arocha, J.F. (1990) Comprehending Instructions for Using Pharmaceutical Products in Rural Kenya. Instructional Science, 90, 71-84.

[39] Sojourner, R.J. and Wogalter, M.S. (1998) The Influence of Pictorials on the Comprehension and Recall of Pharmaceutical Safety and Warning Information. International Journal of Cognitive Ergonomics, 2, 93-106.

[40] Sadoski, M., Goetz, E.T. and Fritz, J.B. (1993) Impact of Concreteness on Comprehensibility, Interest, and Memory for Text: Implications for Dual Coding Theory and Text Design. Journal of Educational Psychology, 85, 291-304. 
https://doi.org/10.1037/0022-0663.85.2.291

[41] Roter, D.L., Rudd, R.E., Keogh, J. and Robinson, B. (1987) Worker Produced Health Education Material for the Construction Trades. International Quarterly of Community Health Education, 7, 109-121. https://doi.org/10.2190/FJPL-N1RH-829Q-PQRJ

[42] Whatley, S., Mamdani, M. and Upshur, R.E. (2002) A Randomized Comparison of the Effect of Three Patient Information Leaflet Models on Older Patients' Treatment Intentions. British Journal of General Practice, 52, 483-484.

[43] Houts, P., Doak, C., Doak, L. and Loscalzo, M. (2006) The Role of Pictures in Improving Health Communication: A Review of Research on Attention, Comprehension, Recall, and Adherence. Patient Education and Counseling, 61, 173-190. https://doi.org/10.1016/j.pec.2005.05.004

[44] United States Department of Agriculture (2018) ChooseMyplate.gov. https://www.choosemyplate.gov/

[45] Lutes, L.D., Winett, R.A., Barger, S.D., Wojcik, J.R., Herbert, W.G., Nickols-Richardson, S.M. and Anderson, E.S. (2008) Small Changes in Nutrition and Physical Activity Promote Weight Loss and Maintenance: 3-Month Evidence from the ASPIRE Randomized Trial. Annals of Behavioral Medicine, 35, 351-357. https://doi.org/10.1007/s12160-008-9033-Z

[46] Paivio, A. (1986) Mental Representations: A Dual-Coding Approach. Oxford University Press, New York.

[47] Paivio, A. (1991) Dual Coding Theory: Retrospect and Current Status. Canadian Journal of Psychology, 45, 255-287.

[48] Sadoski, M. and Paivio, A. (2001) Imagery and Text: A Dual Coding Theory of Reading and Writing. Routledge, New York.

[49] Paivio, A. and Csapo, K. (1973) Picture Superiority in Free Recall: Imagery or Dual Coding? Cognitive Psychology, 5, 176-206.

[50] Richardson, A. (1983) Imagery: Definition and Types. In: Sheikh, A.A., Ed., Imagery: Current Theory, Research, and Application, Wiley, New York, 3-42.

[51] Schraw, G., Bruning, R. and Svoboda, C. (1995) Sources of Situational Interest. Journal of Reading Behavior, 27, 1-17. https://doi.org/10.1080/10862969509547866

[52] Clark, J.M. and Paivio, A. (1991) Dual Coding Theory and Education. Educational Psychology Review, 3, 149-210.

[53] Wharton, W.P. (1980) Higher Imagery and the Readability of College History Texts. Journal of Mental Imagery, 4, 129-147.

[54] Sadoski, M. (2001) Resolving the Effects of Concreteness on Interest, Comprehension, and Learning Important Ideas from Text. Educational Psychology Review, 13, 263-281.

[55] Sadoski, M. and Quast, Z. (1990) Reader Response and Long-Term Recall for Journalistic Text: The Roles of Imagery, Affect, and Importance. Reading Research Quarterly, 25, 256-272.

[56] Sadoski, M., Goetz, E.T. and Avila, E. (1995) Concreteness Effects in Text Recall: Dual Coding or Context Availability? Reading Research Quarterly, 30, 278-288.

[57] Sadoski, M., Goetz, E.T. and Rodriguez, M. (2000) Engaging Texts: Effects of Concreteness on Comprehensibility, Interest, and Recall in Four Text Types. Journal of Educational Psychology, 92, 85-95. https://doi.org/10.1037/0022-0663.92.1.85

[58] Mio, J.S. (1996) Metaphor, Politics, and Persuasion. In: Mio, J.S. and Katz, A.N., Eds., Metaphor. Implications and Applications, Lawrence Erlbaum Associates, 
Mahwah, 127-146.

[59] Gentner, D. and Markman, A. (1997) Structure Mapping in Analogy and Similarity. American Psychologist, 52, 45-56. https://doi.org/10.1037/0003-066X.52.1.45

[60] Sopory, P. and Dillard, J.P. (2002) The Persuasive Effects of Metaphor: A Meta-Analysis. Human Communication Research, 28, 382-419. https://doi.org/10.1111/j.1468-2958.2002.tb00813.x

[61] Kintsch, W. (1980) Learning from Text, Levels of Comprehension, or: Why Anyone Would Read a Story Anyway. Poetics, 9, 87-98.

[62] Yiend, J. (2010) The Effects of Emotion on Attention: A Review of Attentional Processing of Emotional Information. Cognition and Emotion, 24, 3-47. https://doi.org/10.1080/02699930903205698

[63] Carretié, L. (2014) Exogenous (Automatic) Attention to Emotional Stimuli: A Review. Cognitive, Affective, \& Behavioral Neuroscience, 14, 1228-1258.

[64] Schmolck, H., Buffalo, E.A. and Squire, L.R. (2000) Memory Distortions Develop over Time: Recollections of the O.J. Simpson Trial Verdict after 15 and 32 Months. Psychological Science, 11, 39-45. https://doi.org/10.1111/1467-9280.00212

[65] Buchanan, T.W. and Adolphs, R. (2002) The Role of the Human Amygdala in Emotional Modulation of Long Term Declarative Memory. In: Moore, S. and Oaksford, M., Eds., Emotional Cognition: From Brain to Behavior, Benjamins, Amsterdam, 9-34. https://doi.org/10.1075/aicr.44.02buc

[66] Hamann, S. (2001) Cognitive and Neural Mechanisms of Emotional Memory. Trends in Cognitive Sciences, 5, 394-400. https://doi.org/10.1016/S1364-6613(00)01707-1

[67] Bradley, M.M., Greenwald, M.K., Petry, M.C. and Lang, P.J. (1992) Remembering Pictures: Pleasure and Arousal in Memory. Journal of Experimental Psychology: Learning, Memory, and Cognition, 18, 379-390. https://doi.org/10.1037/0278-7393.18.2.379

[68] Cahill, L. and McGaugh, J.L. (1995) A Novel Demonstration of Enhanced Memory Associated with Emotional Arousal. Consciousness and Cognition, 4, 410-421.

[69] Kensinger, E.A., Brierley, B., Medford, N., Growdon, J.H. and Corkin, S. (2001) The Effect of Normal Aging and Alzheimer's Disease on Emotional Memory. Emotion, 2, 118-134. https://doi.org/10.1037/1528-3542.2.2.118

[70] Cahill, L., Haier, R.J., Fallon, J., Alkire, M.T., Tang, C., Mcgaugh, J., et al. (1996) Amygdala Activity at Encoding Correlated with Long-Term, Free Recall of Emotional Information. Proceedings of the National Academy of Sciences of the United States of America, 93, 8016-8021. https://doi.org/10.1073/pnas.93.15.8016

[71] McGaugh, J. (2004) The Amygdala Modulates the Consolidation of Memories of Emotionally Arousing Experiences. Annual Review of Neuroscience, 27, 1-28. https://doi.org/10.1146/annurev.neuro.27.070203.144157

[72] Kensinger, E. and Schacter, D. (2006) Amygdala Activity Is Associated with the Successful Encoding of Item, but Not Source, Information for Positive and Negative Stimuli. Journal of Neuroscience, 26, 2564-2570.

[73] Davidson, R. and Irwin, W. (1999) The Functional Neuroanatomy of Emotion and Affective style. Trends in Cognitive Sciences, 3, 11-21. https://doi.org/10.1016/S1364-6613(98)01265-0

[74] Baas, D., Aleman, A. and Kahn, R. (2004) Lateralization of Amygdala Activation: A Systematic Review of Functional Neuroimaging Studies. Brain Research Reviews, 45, 96-103. 
[75] Heart \& Stroke Foundation (2013). https://www.youtube.com/watch?v=Qo6QNU8kHxI

[76] Shoemaker, S.J., Wolf, M.S. and Brach, C. (2013) The Patient Education Materials Assessment Tool (PEMAT) and User's Guide. Agency for Healthcare Research and Quality, Rockville.

[77] Doak, C., Doak, L. and Root, J. (1996) Teaching Patients with Low Literacy Skills. 2nd Edition, Lippincott Company, Philadelphia.

[78] Centers for Disease Control \& Prevention (CDC) (2014). http://www.cdc.gov/ccindex/

[79] Brega, A.G., Barnard, J., Mabachi, N.M., Weiss, B.D., DeWalt, D.A., Brach, C., et al. (2015) AHRQ Health Literacy Universal Precautions Toolkit. 2nd Edition, Agency for Healthcare Research and Quality, Rockville.

[80] Centers for Medicare \& Medicaid Services (2012) Toolkit for Making Written Material Clear and Effective.

https://www.cms.gov/Outreach-and-Education/Outreach/WrittenMaterialsToolkit/ index.html?redirect=/writtenmaterialstoolkit/

[81] Centers for Disease Control and Prevention (2009) Simply Put: A Guide for Creating Easy-to-Understand Materials. Centers for Disease Control and Prevention, Atlanta. https://www.cdc.gov/healthliteracy/pdf/Simply_Put.pdf

[82] National Institutes of Health, National Cancer Institute (US) (2016) Clear \& Simple: Developing Effective Print Materials for Low-Literate Readers.

https://www.nih.gov/institutes-nih/nih-office-director/office-communications-publ ic-liaison/clear-communication/clear-simple

[83] National Institutes of Health, National Library of Medicine (US) (2017) How to Write Easy-to-Read Health Materials. https://medlineplus.gov/etr.html 